\title{
Herpes zoster vaccination in Australia: what's available and who benefits?
}

\section{Sanjay Jayasinghe \\ Research fellow' \\ Senior lecturer ${ }^{2}$ \\ Sarah Sheridan \\ Public health physician' \\ Research fellow ${ }^{3}$ \\ Kristine Macartney \\ Director \\ Professor ${ }^{2}$ \\ ${ }^{1}$ National Centre for Immunisation Research and Surveillance, Kids Research, The Children's Hospital at Westmead, Sydney \\ ${ }^{2}$ Discipline of Child and Adolescent Health, Faculty of Medicine and Health, University of Sydney \\ ${ }^{3}$ School of Public Health and Community Medicine, UNSW Medicine, University of New South Wales, Sydney}

\section{Keywords}

herpes zoster,

immunisation, postherpetic neuralgia, shingles, zoster vaccines

Aust Prescr 2020;43:2-6 https://doi.org/10.18773/ austprescr.2020.001

\section{SUMMARY}

Acute herpes zoster and associated postherpetic neuralgia is caused by reactivation of latent varicella zoster virus. It can be debilitating for older adults and interfere with activities of daily living.

A live, attenuated single-dose vaccine, that protects against both acute herpes zoster and postherpetic neuralgia, is available for free to all Australians aged 70 years, and in a catch-up program for those aged 71-79 years.

The vaccine is contraindicated in people who are immunocompromised, but can be considered in those who are receiving low doses of selected disease-modifying antirheumatic drugs.

Records of the Australian Immunisation Register suggest that only a third of 70 year olds received the vaccine in the first year-and-a-half of the program. This is likely an underestimation, but emphasises the importance of ensuring the vaccine is offered to all eligible patients and that vaccination is recorded on the Register.

A non-live recombinant herpes zoster vaccine has recently been developed which is more efficacious than the live vaccine in clinical trials. It is registered in Australia but not currently available.

\section{Introduction}

Herpes zoster, commonly known as shingles, typically presents as a unilateral, painful vesicular rash with a distinctive dermatomal distribution. It is caused by reactivation of latent varicella zoster virus from dorsal nerve root ganglia following primary infection (chickenpox), often many decades earlier., ${ }^{1,2}$

The main trigger of virus reactivation is thought to be related to a decline in varicella zoster virus-specific cell-mediated immunity that occurs naturally with ageing (immunosenescence), or as a consequence of immunosuppression (from disease or medical therapy). ${ }^{3,4}$ In the majority of cases, herpes zoster resolves on its own. However, it causes significant discomfort, particularly to older people who have the highest risk of developing postherpetic neuralgia. This is characterised by debilitating pain and dysaesthesia persisting for more than three months. ${ }^{5}$

In Australia around 120,000 new cases of herpes zoster occur each year and account for approximately one in 1000 of all GP visits. ${ }^{6,7}$ Although it can occur at any age after primary infection, the risk of herpes zoster and postherpetic neuralgia increases substantially from 50 years of age onward. ${ }^{6}$ People who live to age 85 years have approximately a $50 \%$ risk of developing herpes zoster. ${ }^{5}$

A recent large study from the USA suggests there is no impact of the childhood chickenpox vaccination program on the incidence of herpes zoster in adults. ${ }^{8}$

\section{Why vaccinate against herpes zoster?}

Almost all adults in Australia have been infected with the varicella zoster virus and are therefore at risk of developing herpes zoster. ${ }^{9,10}$ Pain accompanies herpes zoster in about $80 \%$ of patients aged over 50 years, and varies from burning to lancinating pain, sometimes with paraesthesia, anaesthesia or allodynia. ${ }^{3}$

Antiviral therapy (valaciclovir or famciclovir) given within 72 hours of rash onset can help resolve acute pain and accelerate the healing of skin lesions. However, it is thought to have little or no effect on the likelihood of developing postherpetic neuralgia."

Postherpetic neuralgia is problematic because it can be refractory to treatment with analgesics, neuroleptics and other drugs, and can last for months and even years. ${ }^{12,13}$ In older adults it often interferes substantially with activities of daily living and can have a very negative impact on overall well-being. . $^{14,15}$

Vaccination protects individuals from herpes zoster and postherpetic neuralgia and reduces associated medical and psychosocial outcomes and costs for the patient. ${ }^{3,13}$ The limited impact of current treatment for herpes zoster and postherpetic neuralgia makes vaccination a particularly important strategy to spare older Australians this debilitating disease. ${ }^{16}$ 


\section{Recommendations for vaccination}

A live attenuated vaccine against herpes zoster (Zostavax) was licensed in Australia in 2006. The vaccine contains approximately 14 times more attenuated varicella zoster virus (Oka strain) than the licensed chickenpox vaccines - this higher concentration is needed to produce a T-cell boosting response.

Since November 2016 the live vaccine has been offered through the National Immunisation Program to adults aged 70 years, and to those aged 71-79 years in a five-year catch-up program. It is contraindicated in individuals with significant immunosuppression due to disease or therapy.

Zoster vaccine is funded for people aged 70-79 years because they are expected to benefit the most. People in this age group have a higher risk of herpes zoster and postherpetic neuralgia compared to those aged 50-69 years.

Zostavax is registered for use from 50 years of age and is recommended in the Australian Immunisation Handbook for all immunocompetent adults aged 60 years and older. ${ }^{17}$ Routine administration from 50-59 years is not recommended because of the relatively low disease incidence and because waning vaccine immunity in the 5-10 years after vaccination would result in insufficient protection when reaching an older age.

Age 70-79 years is considered the best time to target the one-dose vaccine so protection lasts until people reach their $80 \mathrm{~s}$, when disease risk is highest. The efficacy of the vaccine is low after 80 years of age, but individual benefit is still likely.

People aged 50-69 years and over 80 years who wish to receive the vaccine have to obtain a prescription and pay for it. Zoster vaccination is recommended for household contacts (aged $\geq 50$ years) of anyone who is immunocompromised (currently or expected to be). This reduces the likelihood of exposure to shedding virus for the immunocompromised person. ${ }^{17}$

The vaccine can be given at the same visit as other inactivated or live vaccines, including pneumococcal vaccine. ${ }^{17}$ It is also safe to give to someone who has had a previous episode of herpes zoster, to prevent recurrence. However, because herpes zoster itself provides an immune boost, vaccination is not recommended until at least 1-3 years after the initial herpes zoster episode. ${ }^{17}$

The lifetime risk of recurrent herpes zoster is 1-5\%.18,19 Repeat (booster) doses of Zostavax are not currently recommended or funded but a subsequent dose 10 years after a first dose is safe and results in an immune boost. ${ }^{20}$ Checking for evidence of past chickenpox by serology is not required before vaccination, except in special circumstances such as HIV infection or before transplant.

\section{How effective is the live vaccine?}

In the Shingles Prevention Study (40,000 adults aged 60 years and over), vaccine efficacy against herpes zoster was $51 \%$ and against postherpetic neuralgia was $67 \%$, in three years of follow-up (see Table). ${ }^{21}$ When follow-up was extended to 4-7 years, vaccine protection against herpes zoster declined to approximately $40 \%$ but remained around $60 \%$ against postherpetic neuralgia. ${ }^{22}$ After 7-11 years, efficacy declined further to $21 \%$ for herpes zoster and $35 \%$ for postherpetic neuralgia. ${ }^{23}$ Protection against herpes zoster was less when the vaccine was given to adults over 70 years of age (the target National Immunisation Program age group) compared to when it was given to those aged 60-69 years. However, there appeared to be no difference in the protection against postherpetic neuralgia in the short term between these two age groups. Essentially, vaccination still modified the severity of the herpes zoster burden of illness. ${ }^{21}$

The impacts of vaccination have also been confirmed in post-licensure studies in the UK and USA. ${ }^{24-27}$ In the UK, vaccine uptake by $70-79$ year olds reached $58-72 \%$ and effectiveness in the first three years was $62 \%$ against herpes zoster and $70-88 \%$ against postherpetic neuralgia (see Table). ${ }^{24}$ In the USA, where the vaccine was given to people aged 60 years and older, its effectiveness in the first year was higher for more severe herpes zoster outcomes (77\% for hospitalised herpes zoster, $70 \%$ for postherpetic neuralgia) compared to herpes zoster in outpatients (38\%). Protection against more severe herpes was also better preserved over the seven year observation period. ${ }^{25}$

\section{Table Efficacy of the live herpes zoster vaccine (Zostavax) in adults aged 60 years and over}

\begin{tabular}{|c|c|c|c|c|}
\hline & & \multicolumn{3}{|c|}{ Vaccine protection at follow-up period } \\
\hline \multicolumn{2}{|c|}{ Study } & 3 years & 4-7 years & 7-11 years \\
\hline \multirow{2}{*}{$\begin{array}{l}\text { Shingles Prevention } \\
\text { Study ( } \geq 60 \text { years) }{ }^{21-23}\end{array}$} & herpes zoster & $51 \%$ & $40 \%$ & $21 \%$ \\
\hline & $\begin{array}{l}\text { postherpetic } \\
\text { neuralgia }\end{array}$ & $67 \%$ & $60 \%$ & $35 \%$ \\
\hline \multirow{2}{*}{$\begin{array}{l}\text { Post-licensure study } \\
\text { in UK (>70 years) }{ }^{24}\end{array}$} & herpes zoster & $62 \%$ & - & - \\
\hline & $\begin{array}{l}\text { postherpetic } \\
\text { neuralgia }\end{array}$ & $70-88 \%$ & - & - \\
\hline
\end{tabular}




\section{Safety of live vaccine}

Post-licensure safety data from the USA and Australia have confirmed the good safety profile of the live vaccine. ${ }^{28,29}$ In clinical trials the vaccine was well tolerated in adults aged 50 years and older, with only mild and transient (not lasting more than four days) injection-site reactions, such as pain, swelling, erythema or pruritus, reported by about $50 \%$ of vaccine recipients. However, two deaths associated with inappropriate administration of the vaccine to severely immunocompromised individuals have been reported. ${ }^{30,31}$ It is therefore absolutely essential to check patients for immune suppression (medical history, medicines) before giving the vaccine.

\section{Contraindications to live vaccine}

Because the vaccine contains live attenuated virus, it is contraindicated in people who are currently or have been recently severely immunocompromised, due to primary or acquired medical conditions or from medical treatment.

Detailed guidelines regarding vaccination of individuals on immunosuppressive therapy are given in the Australian Immunisation Handbook. ${ }^{17}$ However, it is not possible to provide prescriptive evidencebased advice on all individual circumstances, given the wide range of medical conditions and immunemodulating drug therapies. If there is uncertainty regarding a patient's level of immunosuppression, discussion with the treating or infectious disease specialist is recommended. For example, the live vaccine can be given to people taking low doses of some disease-modifying antirheumatic drugs (azathioprine, methotrexate and mercaptopurine) or denosumab, who are not otherwise severely immunocompromised.

The vaccine is also contraindicated in pregnant women, and those who have had anaphylaxis to the vaccine (either Zostavax or varicella vaccine) or its components (including gelatin or neomycin). ${ }^{17}$

\section{Australian experience with live vaccine}

The implementation, coverage and safety of the Australian live vaccine program has been evaluated in older adults. ${ }^{29}$ Disappointingly, in the first 17 months of the program, vaccine uptake was only $34 \%$ in 70 year olds and $26 \%$ in $71-79$ year olds according to the Australian Immunisation Register. Uptake was higher among indigenous Australians but varied across jurisdictions. These low estimates of coverage are likely, in part, due to under-reporting by GPs as the number of Zostavax doses distributed under the National Immunisation Program was almost double the number recorded in the Immunisation Register. This highlights the critical need for immunisation providers to ensure vaccination is documented and the data are transmitted to the Register for all vaccines.

Adverse events following immunisation should be reported to the Therapeutic Goods Administration Adverse Events Management System. Events are also captured by AusVaxSafety, which is an active participant-based system that has surveyed around 15,000 patients about their experiences after vaccination. ${ }^{29,32}$ The vaccine safety profile is consistent with what was expected, when used as recommended. The majority of notifications to both systems were injection-site reactions and rash, which were mild and resolved spontaneously.

The impact of the zoster vaccination program on disease incidence in Australian has not yet been assessed.

\section{Recombinant subunit zoster vaccine}

There is a new herpes zoster recombinant subunit adjuvanted vaccine ( $\mathrm{HZ} / \mathrm{su}$, Shingrix). It is not a live vaccine and requires a two-dose schedule with approximately 2-6 months between doses. The vaccine was registered in Australia in 2017 for people aged 50 years and above. However, it is not yet available for use. There is reportedly a limited global supply.

In 2018, an application by the manufacturer to include the $\mathrm{HZ} / \mathrm{su}$ vaccine on the National Immunisation Program was unsuccessful due to uncertainty regarding cost-effectiveness. This vaccine is registered and used in some other countries, including the USA where the Centres for Disease Control and Prevention recommend it in preference to the live attenuated vaccine. ${ }^{33}$

The recombinant vaccine is more efficacious and more reactogenic than the live vaccine. In clinical trials, it provided $97 \%$ protection against herpes zoster for $50-59$ year olds and $91 \%$ for those aged over 70 years. ${ }^{34,35}$ Similar levels of protection were observed against postherpetic neuralgia over more than three years. Overall in those aged over 70 years, more people vaccinated with the recombinant vaccine than with placebo reported adverse events that prevented normal everyday activity in the week following vaccination (grade 3 injection-site reactions: $8.5 \%$ vs $0.2 \%$, and grade 3 systemic reactions: $6 \%$ vs $2 \%){ }^{34}$ Monitoring during the first eight months of its use in the USA has found the vaccine's safety profile to be consistent with pre-licensure trials. ${ }^{36}$ Importantly, the recombinant vaccine can potentially be used in immunocompromised people. To date, only a limited number of clinical trials in this population have been published with most reporting only 
immunogenicity or safety. However, a recent study has found that two doses of the vaccine provide $68 \%$ protection against herpes zoster in people who have undergone autologous haemopoietic stem-cell transplant. ${ }^{37}$ Several other trials in immunocompromised people have shown the vaccine has an acceptable safety profile. ${ }^{38-40}$

\section{Conclusion}

Immunisation against herpes zoster and postherpetic neuralgia using a live attenuated vaccine (Zostavax) is available under the National Immunisation Program for Australians who are 70-79 years of age. It provides modest protection against these severe and dreaded conditions that are common in older adults. Data from large post-licensure studies confirm the effectiveness and safety of this vaccine, when used according to recommendations. GPs should ensure they check patients for immunocompromising conditions before giving the live vaccine.

The uptake of Zostavax recorded on the Australian Immunisation Register is low and it is strongly recommended that GPs offer the vaccine to eligible patients and ensure administration is reported on the Australian Immunisation Register. A more efficacious non-live vaccine against herpes zoster has been registered but is not yet available in Australia. $<$

Conflict of interest: none declared

\section{REFERENCES}

1. Dwyer DE, Cunningham AL. 10: Herpes simplex and varicellazoster virus infections. Med J Aust 2002;177:267-73. https://doi.org/10.5694/j.1326-5377.2002.tb04764.x

2. Hope-Simpson RE. The nature of herpes zoster: a long-term study and a new hypothesis. Proc R Soc Med 1965;58:9-20. https://doi.org/10.1177/003591576505800106

3. Cunningham AL, Breuer J, Dwyer DE, Gronow DW, Helme RD, Litt JC, et al. The prevention and management of herpes zoster. Med J Aust 2008:188:171-6. https://doi.org/ 10.5694/j.1326-5377.2008.tb01566.x

4. Miller AE. Selective decline in cellular immune response to varicella-zoster in the elderly. Neurology 1980;30:582-7. https://doi.org/10.1212/WNL.30.6.582

5. Cohen JI. Clinical practice: Herpes zoster. N Engl J Med 2013;369:255-63. https://doi.org/10.1056/NEJMcp1302674

6. MacIntyre R, Stein A, Harrison C, Britt H, Mahimbo A, Cunningham $A$. Increasing trends of herpes zoster in Australia. PLoS One 2015;10:e0125025. https://doi.org/ 10.1371/journal.pone.0125025

7. Nelson MR, Britt HC, Harrison CM. Evidence of increasing frequency of herpes zoster management in Australian general practice since the introduction of a varicella vaccine. Med J Aust 2010;193:110-3. https://doi.org/10.5694/ j.1326-5377.2010.tb03818.x

8. Harpaz R. Do varicella vaccination programs change the epidemiology of herpes zoster? A comprehensive review, with focus on the United States. Expert Rev Vaccines 2019;18:793-811. https://doi.org/10.1080/14760584.2019.1646129

9. Gidding HF, Maclntyre CR, Burgess MA, Gilbert GL. The seroepidemiology and transmission dynamics of varicella in Australia. Epidemiol Infect 2003;131:1085-9. https://doi.org/ $10.1017 /$ S0950268803001134

10. Ward K, Dey A, Hull B, Quinn HE, Macartney K, Menzies R. Evaluation of Australia's varicella vaccination program for children and adolescents. Vaccine 2013;31:1413-9. https://doi.org/10.1016/j.vaccine.2012.12.052

11. Chen N, Li Q, Yang J, Zhou M, Zhou D, He L. Antiviral treatment for preventing postherpetic neuralgia. Cochrane Database Syst Rev 2014:CD006866.

12. Johnson RW, Rice AS. Clinical practice. Postherpetic neuralgia. N Engl J Med 2014;371:1526-33. https://doi.org/ 10.1056/NEJMcp1403062

13. Oxman MN, Levin MJ; Shingles Prevention Study Group. Vaccination against herpes zoster and postherpetic neuralgia. J Infect Dis 2008;197 Suppl 2:S228-36. https://doi.org/10.1086/522159

14. Johnson RW, Bouhassira D, Kassianos G, Leplège A, Schmader KE, Weinke T. The impact of herpes zoster and post-herpetic neuralgia on quality-of-life. BMC Med 2010;8:37. https://doi.org/10.1186/1741-7015-8-37

15. Lukas K, Edte A, Bertrand I. The impact of herpes zoster and post-herpetic neuralgia on quality of life: patientreported outcomes in six European countries. J Public Health 2012;20:441-51. https://doi.org/10.1007/s10389-011-0481-8
16. Schmader KE, Johnson GR, Saddier P, Ciarleglio M, Wang WW Zhang JH, et al.; Shingles Prevention Study Group. Effect of a zoster vaccine on herpes zoster-related interference with functional status and health-related quality-of-life measures in older adults. J Am Geriatr Soc 2010;58:1634-41. https://doi.org/10.1111/j.1532-5415.2010.03021.x

17. Australian Technical Advisory Group on Immunisation. Australian Immunisation Handbook. Canberra: Australian Government Department of Health; 2018.

https://immunisationhandbook.health.gov.au [cited 2019 Dec 24]

18. Ragozzino MW, Melton LJ 3rd, Kurland LT, Chu CP, Perry HO. Population-based study of herpes zoster and its sequelae. Medicine (Baltimore) 1982;61:310-6. https://doi.org/10.1097/ 00005792-198209000-00003

19. Yawn BP, Wollan PC, Kurland MJ, St Sauver JL, Saddier P. Herpes zoster recurrences more frequent than previously reported. Mayo Clin Proc 2011;86:88-93. https://doi.org/ 10.4065/mcp.2010.0618

20. Levin MJ, Schmader KE, Pang L, Williams-Diaz A, Zerbe G, Canniff J, et al. Cellular and humoral responses to a second dose of herpes zoster vaccine administered 10 years after the first dose among older adults. J Infect Dis 2016;213:14-22. https://doi.org/10.1093/infdis/jiv480

21. Oxman MN, Levin MJ, Johnson GR, Schmader KE, Straus SE, Gelb LD, et al.; Shingles Prevention Study Group. A vaccine to prevent herpes zoster and postherpetic neuralgia in older adults. N Engl J Med 2005;352:2271-84. https://doi.org/ 10.1056/NEJMoa051016

22. Schmader KE, Oxman MN, Levin MJ, Johnson G, Zhang JH, Betts R, et al.; Shingles Prevention Study Group. Persistence of the efficacy of zoster vaccine in the Shingles Prevention Study and the Short-Term Persistence Substudy. Clin Infect Dis 2012;55:1320-8. https://doi.org/10.1093/cid/cis638

23. Morrison VA, Johnson GR, Schmader KE, Levin MJ, Zhang JH, Looney DJ, et al.; Shingles Prevention Study Group. Long-term persistence of zoster vaccine efficacy. Clin Infect Dis 2015;60:900-9. https://doi.org/10.1093/cid/ ciu918

24. Amirthalingam G, Andrews N, Keel P, Mullett D, Correa A, de Lusignan $\mathrm{S}$, et al. Evaluation of the effect of the herpes zoster vaccination programme 3 years after its introduction in England: a population-based study. Lancet Public Health 2018;3:e82-90. https://doi.org/10.1016/S2468-2667(17)30234-7

25. Izurieta HS, Wernecke M, Kelman J, Wong S, Forshee R, Pratt D, et al. Effectiveness and duration of protection provided by the live-attenuated herpes zoster vaccine in the Medicare population ages 65 years and older. Clin Infect Dis 2017;64:785-93. https://doi.org/10.1093/cid/ciw854

26. Langan SM, Smeeth L, Margolis DJ, Thomas SL. Herpes zoster vaccine effectiveness against incident herpes zoster and post-herpetic neuralgia in an older US population: a cohort study. PLoS Med 2013;10:e1001420. https://doi.org/ 10.1371/journal.pmed.1001420 
27. Tseng HF, Harpaz R, Luo Y, Hales CM, Sy LS, Tartof SY, et al. Declining effectiveness of herpes zoster vaccine in adults aged $\geq 60$ years. J Infect Dis 2016;213:1872-5. https://doi.org/ 10.1093/infdis/jiw047

28. Miller ER, Lewis P, Shimabukuro TT, Su J, Moro P, Woo EJ, et al. Post-licensure safety surveillance of zoster vaccine live (Zostavax ${ }^{\circledR}$ ) in the United States, Vaccine Adverse Event Reporting System (VAERS), 2006-2015. Hum Vaccin Immunother 2018;14:1963-9. https://doi.org/ 10.1080/21645515.2018.1456598

29. National Centre for Immunisation Research and Surveillance. Evaluation of the National Shingles Vaccination Program: process and early impact evaluation. Sydney: NCIRS; 2019. http://ncirs.org.au/sites/default/files/2019-04/Shingles\%20 Program\%20Evaluation\%20Report_1\%20March\%202019_ Final\%20for\%20web.pdf [cited 2019 Dec 24]

30. Alexander KE, Tong PL, Macartney K, Beresford R, Sheppeard V, Gupta M. Live zoster vaccination in an immunocompromised patient leading to death secondary to disseminated varicella zoster virus infection. Vaccine 2018;36:3890-3. https://doi.org/10.1016/j.vaccine.2018.05.078

31. Costa E, Buxton J, Brown J, Templeton KE, Breuer J, Johannessen I. Fatal disseminated varicella zoster infection following zoster vaccination in an immunocompromised patient. BMJ Case Rep 2016;2016: bcr-2015-212688. https://casereports.bmj.com/content/2016/bcr-2015-212688

32. AusVaxSafety [Internet]. Sydney: National Centre for Immunisation Research and Surveillance; 2019. http://www.ausvaxsafety.org.au [cited 2019 Dec 24]

33. Centers for Disease Control and Prevention. Shingrix recommendations. 2018. https://www.cdc.gov/vaccines/ $\mathrm{vpd} /$ shingles/hcp/shingrix/recommendations.html [cited 2019 Dec 24]

34. Cunningham AL, Lal H, Kovac M, Chlibek R, Hwang SJ, Díez-Domingo J, et al.; ZOE-70 Study Group. Efficacy of the herpes zoster subunit vaccine in adults 70 Years of age or older. N Engl J Med 2016;375:1019-32. https://doi.org/10.1056/ NEJMoa1603800

\section{FURTHER READING}

National Centre for Immunisation Research and Surveillance. Zoster vaccine for Australian adults. NCIRS Fact sheet, Aug 2017. http://www.ncirs.org.au/ncirs-fact-sheets-faqs/zoster-vaccineaustralian-adults [cited $2019 \mathrm{Dec} 24$ ]
35. Lal H, Cunningham AL, Godeaux O, Chlibek R Diez-Domingo J, Hwang SJ, et al.; ZOE-50 Study Group. Efficacy of an adjuvanted herpes zoster subunit vaccine in older adults. N Engl J Med 2015;372:2087-96. https://doi.org/ 10.1056/NEJMoa1501184

36. Hesse EM, Shimabukuro TT, Su JR, Hibbs BF, Dooling KL, Goud R, et al. Postlicensure safety surveillance of recombinant zoster vaccine (Shingrix) - United States, October 2017-June 2018. MMWR Morb Mortal Wkly Rep 2019;68:91-4. https://doi.org/10.15585/mmwr.mm6804a4

37. Bastidas A, de la Serna J, El Idrissi M, Oostvogels L, Quittet P, López-Jiménez J, et al.; ZOE-HSCT Study Group Collaborators. Effect of recombinant zoster vaccine on incidence of herpes zoster after autologous stem cell transplantation: a randomized clinical trial. JAMA 2019;322:123-33. https://doi.org/10.1001/jama.2019.9053

38. Berkowitz EM, Moyle G, Stellbrink HJ, Schürmann D, Kegg S, Stoll M, et al.; Zoster-015 HZ/su Study Group. Safety and immunogenicity of an adjuvanted herpes zoster subunit candidate vaccine in HIV-infected adults: a phase 1/2a randomized, placebo-controlled study. J Infect Dis 2015;211:1279-87. https://doi.org/10.1093/infdis/jiu606

39. Stadtmauer EA, Sullivan KM, Marty FM, Dadwal SS, Papanicolaou GA, Shea TC, et al. A phase $1 / 2$ study of an adjuvanted varicella-zoster virus subunit vaccine in autologous hematopoietic cell transplant recipients. Blood 2014;124:2921-9. https://doi.org/10.1182/blood-2014-04-573048

40. Vink P, Ramon Torrell JM, Sanchez Fructuoso A, et al. Immunogenicity and safety of the adjuvanted recombinant zoster vaccine in chronically immunosuppressed adults following renal transplant: a phase III, randomized clinical trial. Clin Infect Dis 2020;70:181-90. https://doi.org/10.1093/ cid/ciz177
National Centre for Immunisation Research and Surveillance. Zoster vaccine - FAQs. NCIRS Fact sheet, Apr 2018. http://www.ncirs.org.au/ncirs-fact-sheets-faqs/zoster-vaccinefaqs [cited 2019 Dec 24] 